\title{
Budgetary Choices And Public Finance Sustainability In Morocco: Empirical Evaluation
}

\author{
Said Toufik, Ability Prof. \\ Saad El Baghdadi, PhD Student
}

ERADIASS / Department of Economics, Faculty of Law and Economics Souissi, Mohammed V University of Rabat

doi: 10.19044/esj.2016.v12n4p180 URL:http://dx.doi.org/10.19044/esj.2016.v12n4p180

\begin{abstract}
This article is designed to measure public finance sustainability in Morocco, to analyze the strength of the relationship between public revenue and expenditures by assessing the quality of budgetary choices. In the light of the results, output budgeting remains a pillar that allows the Moroccan Government to make significant macroeconomic performance.
\end{abstract}

Keywords: Fiscal policies, Sustainability, Stationarity, Cointegration

\section{Introduction}

The main theoretical lessons have demonstrated that healthy public finance constitutes a macroeconomic stability factor (current account, inflation, growth...). The lack of distinction between the influence of temporary and permanent shocks over the budget, in the evaluation and formulation of fiscal policies, can be a major risk on this financial leverage which can be over or under-adjusted in response to the economic requirements and could be reversed automatically on the economic activity.

Like other developing countries, in Morocco the birth of a budget deficit derives from two different sources: one relative to the business cycle in terms of conjuncture and another more sustainable relating to the structure of the economy. The cyclical deficit, seen as an episodic component disappears with the economic cycle improvement. As for the structural deficit, it requires deep reforms and structural adjustment to be eradicated.

Legally, the $77^{\text {th }}$ article of the new Moroccan constitution of $1^{\text {st }}$ July 2011 clearly stipulates that the Parliament and the Government shall ensure the preservation of the balance of government finance. This article, considered, in our view, as a golden budgetary rule which gets in line with the first article of the Organic Law No. 7-98 relating to the Finance Act which defined the budget law itself as a law that forecasts and authorizes for 
each calendar year, all the resources and expenditure of the State within the limits of an economic and financial balance it defines.

This legal arsenal shows how good governance and rationality of budgetary choices can positively influence the relationship between revenues, spending and economic growth. Thus fulfilling the doctrinal aspect of financial orthodoxy.

In this context, how can we evaluate the sustainability of fiscal policy? Does fiscal policy constitute an instrument of economic stability? Are the Morocco budgetary choices effective to smooth the business cycle?

\section{Deficits in Morocco: Between the Cyclical and Structural}

The determination of the trend growth of the national economy is very useful in the conduct of economic policy. Reducing economic imbalances requires, in fact, the distinction between cyclical fluctuations which disappear with the improvement in economic conditions and persistent imbalances that require structural measures.

The calculation of the cyclical deficit is based on trend growth. The derivation of GDP trend goes through the correction of GDP observed of seasonal variations ${ }^{33}$. We used the smoothing method to the Hodrick-Prescott (HP) with the smoothing parameter ${ }^{34} \lambda=100$.

$$
\min _{x_{t}^{*}} \sum_{t=1}^{N}\left[\left(X_{t}-T_{t}\right)^{2}+\lambda\left(\Delta T_{t+1}-\Delta T_{t}\right)^{2}\right]
$$

Although often criticized in the literature, the HP filter is still the most commonly used in empirical studies and policy analysis to identify components of the trend in macroeconomic series ${ }^{35}$.

In Morocco, economic growth is characterized by a saw tooth pattern, marking up and down according to changes in agricultural production which has always been correlated with climatic conditions (rainfall, drought ...). Furthermore, the evolution of growth is characterized by a high volatility which appears to be structural and clutters the proper functioning of the wealth accumulation process. The graph below shows the relationship between the cyclical deficit and the output gap and highlights the following findings:

\footnotetext{
${ }^{33}$ Karim M. (2010), «Viabilité Budgétaire et Financière au Maroc », première édition, Imp. El Maarif Al Jadida.

${ }^{34}$ To calculate the trend or cycle of a series, we used the values recommended by Hodrick and Prescott ( $\lambda=100$ for annual data and $\lambda=1600$ quarterly data).

${ }^{35}$ Bouthevillain C., al. (2001), "Cyclically adjusted budget balances: an alternative approach", September, EUROPEAN CENTRAL BANK, Working Paper $\mathrm{N}^{\circ} 77$.
} 
Figure 1: evolution of the cyclical deficit and the Output Gap in\% of GDP

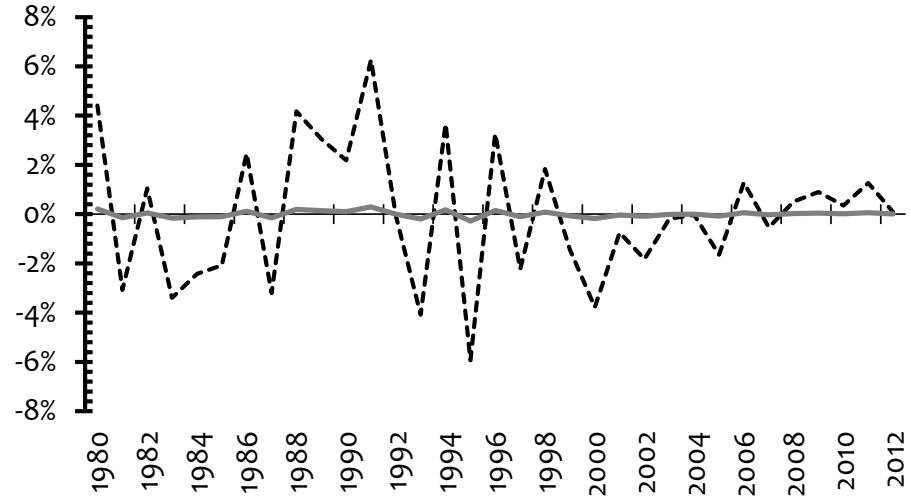

------ Output GAP Cyclical deficit

The impact of the economy on the budget is low. The cyclical deficit does not exceed 1\% of GDP over the period studied. Indeed, during the drought years of 1992, 1993 and 1995, the cyclical deficit has been estimated at respectively $0.01 \%, 0.19 \%$ and $0.28 \%$ of GDP.

With the change in the fiscal calendar ${ }^{36}$, the cyclical deficit has become less important. Thus, in 1996-1997, it was of the order of $0.02 \%$ of GDP, while for the 1997-2012 fiscal year, the effects of the economy have been almost neutralized with slight cyclical surpluses that were recorded during the years 1998, 2004, 2006 and 2008 to 2012. This is explained by the alternation in the 1990s of good and bad crop years.

In terms of the structural deficit, the chart below shows that it is almost close to the overall deficit:

Figure 2: Breakdown of the budget deficit

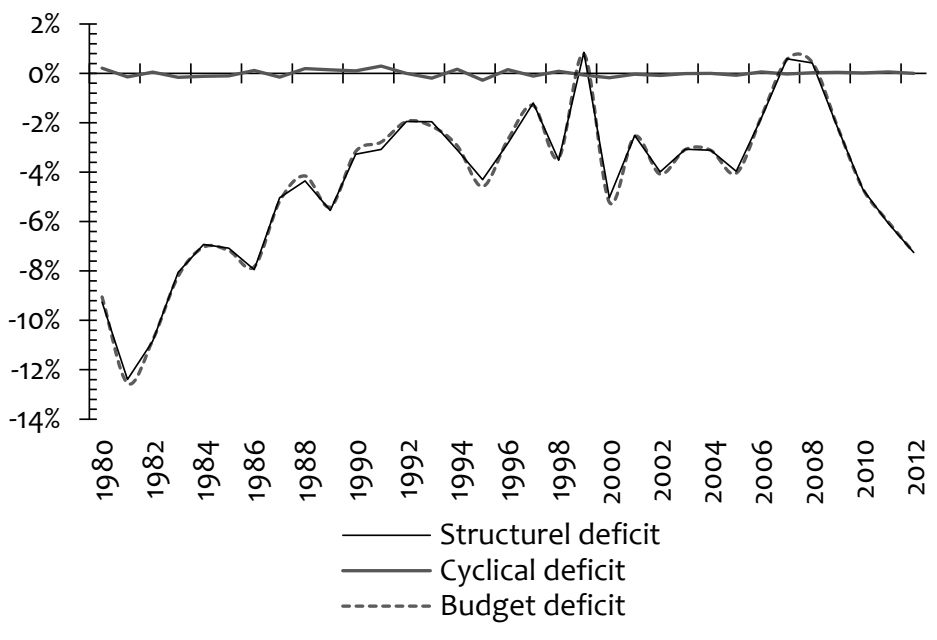

\footnotetext{
${ }^{36}$ These are the dates by which the tax declaration and payment operations should be performed (calendar or fiscal schedule).
} 
The high level of the structural deficit results, on the one hand, from the incompressible nature of the debt, the exploding personnel costs and compensation and, on the other hand, from the low elasticity of tax levies to economic conditions due the narrowness of the tax base.

\section{Sustainability of the Fiscal Policy in Morocco:}

The sustainability issue is part of a framework of good governance and management reflecting relatively performance, effectiveness and efficiency (PEE) of public authorities. Theoretically, sustainability is seen as a condition for stability in a deterministic context and as a stationary condition in a stochastic context. It includes time dimension variables in a structural relationship.

The empirical literature is rich in models that are interested in the debt dynamics and sustainability deficits. These models are divided into two types: accounting models and actuarial models based on statistical analysis. We propose in the following, an empirical assessment of the levels of sustainability of fiscal deficits in Morocco by an economic and statistical analysis at the same time.

\section{Sustainability Analysis According to the Accounting Approach:}

In Morocco, the comparative analysis of the ratio of the sustainable primary balance, achieved by the accounting method in relation to the ratio of primary balance during the period (1980-2012), brought out, at the national level, four distinct phases in the evolution of fiscal policy (phase from 1980 to 1987, from 1988 to 2001, from 2002 to 2007 and the cycle from 2008 to 2012) that we can particularize from the graph below:

Figure 3: Evolution of the achieved primary balance and sustainable primary balance as\% of GDP

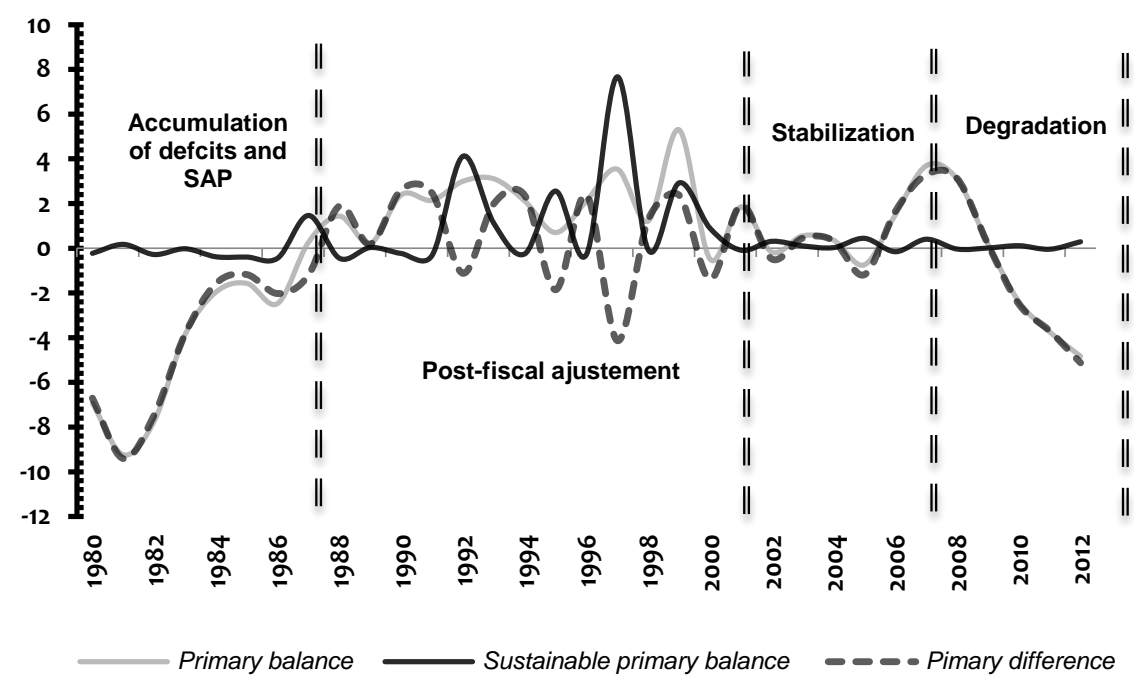


During the first phase 1980 - 1987, the ratio of the primary balance was still below the sustainable level. This shows that the budget choices pursued by the government have generated unsustainable primary deficits. This phase was marked by strong growth in the ratio of public debt (going from $37.24 \%$ to $77.97 \%$ ). The primary differences ${ }^{37}$ reflect the magnitude of the phase shift between levels of expenditure and public resources that vary between $-9.4 \%$ and $-1.2 \%$, confirming the progressive contribution to the debt ratio.

In 1983, Morocco was put under the control of the IMF. The adoption of the Structural Adjustment Programmes (SAPs) and the choice of external debt $^{38}$ reduction helped sustain the debt ratio ${ }^{39}$. These results, combined with a restrictive fiscal policy, helped to regulate the level of the budget deficit in 1984.

The second phase $\mathbf{1 9 8 8}$ - 2001 show that in the years 1987 and 1988, the nominal interest rate on public debt is lower than the nominal growth rate of the economy, while in 1989 the growth rate GDP is low, which was reflected on the primary balance.

Indeed, after the application of restrictive policies adopted under the structural adjustment program, budgetary choices were draconian resulting in a net primary budget deficit increasingly weak and becoming, in 1990, a surplus. As indicated above, the adjustment and rescheduling program ended in $1992^{40}$. Efforts under this program have played an indispensable role in reducing macroeconomic imbalances.

Between 1993 and 2000, one can easily notice the achievement of primary surpluses of around 2.2\% of GDP on average, exceeding the indicators of sustainable deficits. This positive result has improved, on average, debt ratios. Nevertheless, this level of sustainability hides in fact difficulties to maintain the debt service (interest and principal) in their trend started in 1986, since it indicates some deterioration in 2001 (see Figure 3). These difficulties originate from the end of the rescheduling cycle which allowed to reduce the debt burden (interest-only weight), but equally the

\footnotetext{
${ }^{37}$ Primary difference $=$ (primary balance - sustainable primary balance $)$ as $\%$ of GDP. A negative gap means that fiscal policy is unsustainable

38 The ratio of external debt has increased from 2\% to 70\% between 1970 and 1984 before returning to the level of $23 \%$ in 2002.

${ }^{39}$ AMRANI M. R., K. HAMMES, L. OULHAJ (2004), "Etat des finances publiques du Maroc" In Rapport final du projet de recherche FEMISE, NFEM2-02-21-39.

${ }^{40}$ The debt treatment is provided by the Paris Club. Since 1983, Morocco was following debt treatments in classical terms (standard treatment), until 1990 he signed his first Paris Club agreement under which Houston is based on debt conversion clauses in an agreement of debt relief.
} 
poor performance of the national economy in general and in particular international $^{41}$.

The third phase 2002 - 2007, recording a slight decline in the primary balance from the 90's. This result remains stable on average and is set above the sustainable primary balance.

The year 2002 began with a domestic debt which amounted to 197 billion dirhams, representing approximately 68\% of total direct public debt. This increase is mainly due to the increase of funds raised on the auction market. These results are confirmed with the policy applied in the active management framework of the external debt further debt conversion operations in investments and use for the first time in instruments to minimize the risks associated with fluctuations in rates exchange and interest rates. We similarly notice the extent of Treasury's financing needs in 2005 which resulted in an increase of the direct public debt whose total outstanding was $\$ 327.4$ billion and increased by $11.3 \%$ bringing the debt ratio to $71.6 \%$ of GDP instead of $66.3 \%$ in 2004 . This trend is attributable to the expansion of $15.5 \%$ of domestic debt, which reached 258.5 billion, particularly following the clearance of arrears of the government vis-à-vis the Moroccan pension fund ${ }^{42}$.

This is also explained by the issuance of Treasury strategy, adopted in 2007, which resulted in a lower average cost of debt, returning $4.08 \%$ to $3.39 \%$, following the repayment of Treasury, in anticipation of the rescheduled debt towards the London Club in the amount of 272 million dirhams in relation to the Japanese bank for international cooperation.

Finally, the fourth phase 2008 - 2012, is presented in a downtrend form. Coverage of financing needs of the Treasury as well as higher external borrowing have resulted in an increase in the stock of public debt, which indicates complete unsustainability throughout this period. The Moroccan public finances were relatively healthy before the world crisis of 2008, but the trend has significantly deteriorated since then as a result of swelling of spending ${ }^{43}$.

After improving fiscal leeway consecrated by the surpluses achieved in 2007 and 2008, the Treasury situation from the years 2009, 2010 and 2011 generated large deficits of levels, respectively $2.2 \%, 4.7 \%$ and $6.9 \%$ of GDP.

\footnotetext{
${ }^{41}$ Growth hampered by drought and by the combined impact of increased imports of grain and crude oil, knowing that the expansion of these imports led to a deterioration of external indicators.

${ }^{42}$ Rapport annuel de Bank Al Maghrib, 2005.

${ }^{43}$ Alby S. (2013), « Maroc: une économie résistante mais fragile », Economic-Research, BNP Paribas.
} 
In the light of reduced investment expenditures and the repayment of part of the arrears, the Treasury borrowing requirement amounted to $8.2 \%$ of GDP against 5.5\% in 2011. It was covered by nearly 75\% through internal resources. The rest increased to more than half of the international market. These developments have resulted in an increase in Treasury debt ratio, which rose from 53.7\% in 2011 to $59.6 \%$ in 2012, thus further undermining fiscal sustainability ${ }^{44}$. Worse, under the double pressure of the international environment and domestic political climate, the deficit exceeded 6\% of GDP in 2011, settling on $7.25 \%$.

\section{Sustainability Analysis According to the Actuarial Approach}

In order to empirically validate the sustainability issue for the Moroccan economy, we tried to take back Trehan and Walsh (1988) and Jondeau (1992) studies.

Stationarity Test of the Government Budget Balance:

This test demonstrates the stationary character of a chronic by the determination of a deterministic or stochastic trend ${ }^{45}$.

Table 1: Test Hypothesis of the Government budget balance

\begin{tabular}{|c|c|c|}
\hline Applied test & Stationarity test & Sustainability \\
\hline $\begin{array}{c}\text { Augmented Dickey-Fuller } \\
\text { (A.D.F.) }\end{array}$ & $H_{0}:$ Stationarity & Yes \\
\cline { 2 - 3 } & $H_{1}$ : Nonstationarity & No \\
\hline
\end{tabular}

The data used are annual and cover the period 1980-2012 (33 observations). The results of the ADF test for the three models in level and first difference, applied to the series of the overall budget deficit are as follows:

Table 2: Unit root test of the overall budget deficit (ADF)

\begin{tabular}{|c|c|c|c|c|}
\hline \multicolumn{2}{|c|}{ Lags $=1$} & Test value & $\begin{array}{c}\text { Theoretical value } \\
5 \%\end{array}$ & Conclusion \\
\hline \multirow{3}{*}{ Level } & Model (1) & $-1,9353$ & $-1,9521$ & Nonstationarity \\
\cline { 2 - 5 } & Model (2) & $-2,6896$ & $-2,9604$ & Nonstationarity \\
\cline { 2 - 5 } & Model (3) & $-1,3695$ & $-3,5628$ & Nonstationarity \\
\hline \multirow{3}{*}{$1^{\text {st }}$ difference } & Model (1) & $-3,9015$ & $-1,9524$ & Stationarity \\
\cline { 2 - 5 } & Model (2) & $-3,8671$ & $-2,9639$ & Stationarity \\
\cline { 2 - 5 } & Model (3) & $-4,7420$ & $-3,5683$ & Stationarity \\
\hline
\end{tabular}

Source: Author's calculation

According to the test results, we can say that the budget deficit is not stationary in levels, as long as the unit root hypothesis is verified for one of the three models above.

\footnotetext{
${ }^{44}$ Rapport annuel de Bank Al Maghrib, 2005.

${ }^{45}$ Bourbounnais R. (2000), "Econométrie. Manuel et exercices corrigés", Dunod, Paris, troisième édition.
} 
However, first difference, the overall budget deficit is stationary without doubt. This can be explained as the non-verification of a strong sustainability of the overall fiscal deficit of Morocco over the period 19802012.

As for the current budget deficit (without investment), here are the results of the same stationarity tests:

Table 3: Unit root test of the current budget deficit (ADF)

\begin{tabular}{|c|c|c|c|c|}
\hline \multicolumn{2}{|c|}{ Lags $=1$} & Test value & Theoretical value 5\% & Conclusion \\
\hline \multirow{3}{*}{ Level } & Model (1) & $-1,0843$ & $-1,9520$ & Nonstationarity \\
\cline { 2 - 5 } & Model (2) & $-1,9072$ & $-2,9604$ & Nonstationarity \\
\cline { 2 - 5 } & Model (3) & $-1,5354$ & $-3,5628$ & Nonstationarity \\
\hline \multirow{3}{*}{$\begin{array}{c}\text { st } \\
\text { difference }\end{array}$} & Model (1) & $-3,4619$ & $-1,9524$ & Stationarity \\
\cline { 2 - 5 } & Model (2) & $-3,3845$ & $-2,9639$ & Stationarity \\
\cline { 2 - 5 } & Model (3) & $-3,4741$ & $-3,5683$ & Stationarity \\
\hline
\end{tabular}

Source: Author's calculation

The current budget balance is similarly non-stationary in levels and stationary in first differences undoubtedly over the same period. In fact, in the observed case, this hypothesis is true at the 5\% threshold for both the first and for the second model (with constant and without trend).

Finally, both current and overall balances mark an unsustainability in the strong sense. So, is this overall balance weakly sustainable? According to Jondeau, this hypothesis is verified with the application of the Johansen test on revenue and budget expenditures.

\section{Evaluation of revenue and expenditure}

The cointegration test of expenditure and revenue can be possible only when both series are of course non-stationary and integrated of the same order.

Table 4: Hypothesis of Public Revenue and Expenditure Tests

\begin{tabular}{|c|c|c|c|}
\hline Stationarity test & Cointegration test & Johansen test & Sustainability \\
\hline$H_{0}:$ Stationarity & - & - & Yes \\
\hline$H_{1}$ : Nonstationarity & $\begin{array}{c}H_{0}: \text { No } \\
\text { cointegration }\end{array}$ & - & No \\
\hline- & $H_{1}:$ Cointegration & $\begin{array}{c}H_{0}: \text { Cointegration vector } \mathbf{( 1 ; -} \\
\mathbf{1})\end{array}$ & Yes (Strong) \\
\hline- & - & $\begin{array}{c}H_{1}: \text { Cointegration vector } \mathbf{( 1} ;- \\
\boldsymbol{\beta}) \text { avec } \boldsymbol{\beta} \neq \mathbf{1}\end{array}$ & No (Weak) \\
\hline
\end{tabular}

\section{Unit root test}

The results of the ADF test show that revenues and budget expenditures are non-stationary. Likewise, they are integrated of the same order "1" and they show the same stochastic characteristics. Thus, it is possible to proceed with the cointegration of two test series. 


\section{Cointegration test (Johansen)}

The test clearly indicates that we must reject the hypothesis of no cointegration of income and expenditure, (Trace test: $21.29105>$ Theoretical value $" \boldsymbol{\alpha}=\mathbf{5 \% " : ~ 1 5 . 4 9 4 7 1 )}$ and there is at most one cointegrating equation. The normalized cointegrating relationship that makes the hypothesis of a cointegration relationship is given by:

Table 5: Normalized Cointegrating Coefficients

\begin{tabular}{|c|c|}
\hline$d_{t}$ & $r_{t}$ \\
\hline 1 & -0.668294 \\
& $(\mathbf{0 . 0 8 2 4 5})^{*}$ \\
\hline
\end{tabular}

$\left({ }^{*}\right)$ The standard error is presented in brackets Source: Author's calculation

The conclusion that can be retained in the cointegration test of revenue and expenditure is that these two series expose a linear combination which is strictly stationary. Hence, the revenue coefficient has a negative and lower result in absolute value than 1 . These results confirm that Morocco's fiscal policy is sustainable, in the weak sense. The cointegration relationship can be written as follows:

$$
e c_{t}=d_{t}-0.668294 r_{t}
$$

Finally, the chart below (Figure 4$)$ shows the spread-points $\left(d_{t}, r_{t}\right)$ and suggests that stationary linear relationship between the two series:

Figure 4: Linear Relationship of Government Expenditure and Revenue in Millions of Dh

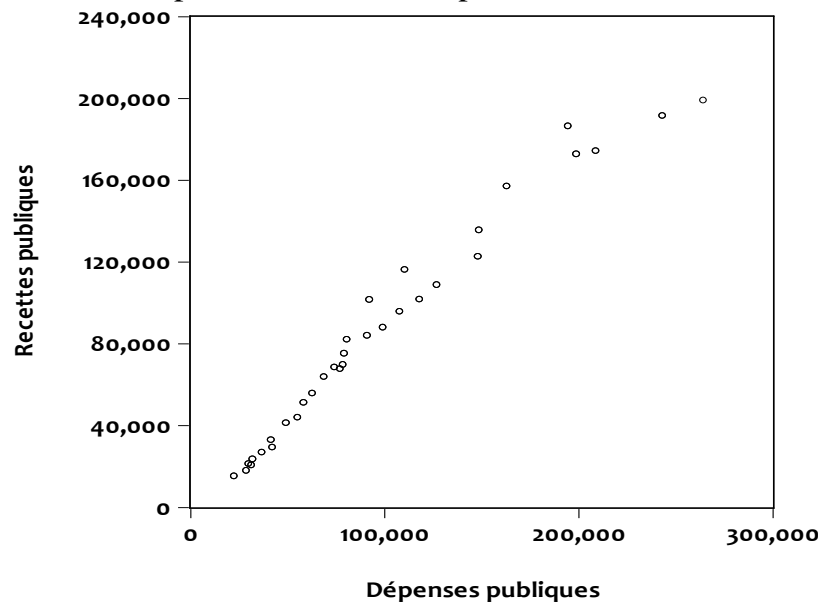

\section{Conclusion}

Even after debt relief, ensuring long-term sustainability remains a major challenge. For now, according to the descriptive analysis, the economic and financial situation is not too alarming.

However, Morocco risks facing a structural problem by satisfying the economic and social requirements; controlling the budget deficit which could 
be highly unsustainable for chronic reasons: (1) Rigidity of deficit reduction, (2) Structural difficulty in mobilizing resources and financing public investment (sectoral plans).

\section{References:}

Amrani M. R., K. Hammes, L. Oulhaj (2004), "Etat des finances publiques du Maroc" In : Rapport final du projet de recherche, Bank Al-Maghrib (2000-2012), Rapports annuels.

Biau O. Et E. Girard (2005), Politique budgétaire et dynamique économique en France : l'approche VAR structurel, Économie et Prévision, nº 169, p. 123.

Blanchard O., J. C. Chouraqui, R. P. Hagemann Et N. Sartor (1990), "La soutenabilité de la politique budgétaire : nouvelles réponses a une question ancienne", Revue économique de l'OCDE, $\mathrm{n}^{\circ} 15$, pp. 7-38.

Boussetta M. (1999), "Finances publiques, contraintes budgétaires et développement économique", Fondation du Roi Abdul Aziz Al Saoud, Casablanca.

Direction des Etudes et des Previsions Financieres, Ministère de l’Economie et des Finances, Royaume Du Maroc (1998), "Déficit structurel et déficit cyclique au Maroc", Document de travail n 33.

Direction des Etudes et des Previsions Financieres, Ministère de l’Economie et des Finances, Royaume du Maroc (1996), "Croissance tendancielle de l'économie marocaine", Document de travail, nº 09.

El Baghdadi S. et S. Toufik (2015), "Croissance économique et soutenabilité de la politique budgétaire au Maroc: évaluation économétrique", Communication présentée au colloque "ATM" à l'Université de Rouen.

El Fakir A. H. (2011), "Production potentielle et écart de production : Application au cas de l'économie marocaine sur des données annuelles", Les Cahiers du Plan, $\mathrm{n}^{\circ} 33$, pp. 21-30.

FEMISE, n ${ }^{\circ}$ FEM 21-39, pp. 85-122.

Henin P.Y. (1997), "Soutenabilité des déficits et ajustements budgétaires". Revue économique. Volume 48, n³, pp. 371-395.

Jondeau E. (1992), La soutenabilité de la politique budgétaire. In : Économie \& prévision, $\mathrm{n}^{\circ} 104$, pp. 1-17.

Karim M., M. Bouzahzah (2006), "Relation causale entre les recettes et les dépenses budgétaires. Un modèle de cointegration et à correction d'erreur appliqué au Maroc", Critique Economique, n 18, pp. 11-22.

Lankaoui L. (2001), "Le déficit public et la soutenabilité de la politique budgétaire", Revue d'économie du développement. I-2, pp. 115-128. 